\title{
Mining
}

\section{Iron removal by precipitate flotation}

\section{Remoção de ferro por flotação de precipitado}

\section{Denise Fontoura Morosini \\ M.Sc, Engenheira Química \\ denisefmorosini@yahoo.com.br}

Carlos Adolpho Magalhães Baltar

D.Sc, Professor Associado IV

Departamento de Engenharia de Minas da

Universidade Federal de Pernambuco

camb@ufpe.br

\section{Antonio Carlos Duarte-Coelho}

D.Sc, Professor Associado IV

Departamento de Engenharia Química da

Universidade Federal de Pernambuco

coelho@ufpe.br

\begin{abstract}
The water from several artesian wells in the metropolitan area of Recife presents high iron content, preventing its use in some industrial processes. The possibility of removing the iron by the use of precipitate flotation using sodium dodecyl sulphate (SDS) as collector was studied. The tests were carried out in a glass column $65 \mathrm{~cm}$ high, fed by a constant airflow.

At $\left.p \mathrm{H} \mathrm{8,} \mathrm{where} \mathrm{the} \mathrm{isoelectric} \mathrm{point} \mathrm{of} \mathrm{colloidal} \mathrm{iron} \mathrm{hydroxide} \mathrm{[} \mathrm{Fe}(\mathrm{OH})_{3}\right]$ was observed, the size of the precipitate increases with conditioning time and facilitates the removal of iron ions by flotation. The results showed that an increase in conditioning time, from 5 to 20 minutes, resulted in a reduction of the residual concentration of iron from 13.2 to $0.2 \mathrm{ppm}$. The decrease in precipitate specific surface area rendered a decrease in the collector consumption possible. The iron ion removal process by flotation using SDS as collector was shown to be quite efficient. A removal of $99 \%$ of $\mathrm{Fe}^{3+}$ contained in the original solution was obtained.
\end{abstract}

Keywords: iron ions flotation; iron removal from water, precipitate flotation; sodium dodecyl sulphate.

\section{Resumo}

A água de poços artesianos, da região metropolitana de Recife, contém um elevado teor de ferro, impedindo o seu uso em alguns processos industriais. Estudou-se a possibilidade de remoção do ferro, por flotação de precipitado, usando-se o dodecil sulfato de sódio (DSS) como coletor. Os testes foram realizados em uma coluna de vidro, com $65 \mathrm{~cm}$ de altura, alimentada por fluxo de ar constante.

$\mathrm{Em} \mathrm{pH} \mathrm{8,} \mathrm{onde} \mathrm{foi} \mathrm{observado} \mathrm{o} \mathrm{ponto} \mathrm{isoelétrico} \mathrm{do} \mathrm{hidróxido} \mathrm{de} \mathrm{ferro} \mathrm{coloidal}$ $\left[\mathrm{Fe}(\mathrm{OH})_{3}\right]$, o tamanho do precipitado aumenta com o tempo de condicionamento, o que favorece a remoção dos íons de ferro por flotação. Os resultados mostraram que um aumento do tempo de condicionamento de 5 para 20 minutos resulta numa redução da concentração residual de ferro de $13,2 \mathrm{ppm}$ para $0,2 \mathrm{ppm}$. A redução da área superficial dos precipitados possibilitou uma redução do consumo do coletor. $\mathrm{O}$ processo de remoção de íons de ferro por flotação, usando DSS como coletor, mostrou-se bastante eficiente. Obteve-se uma remoção de $99 \%$ dos íons de ferro contidos na solução original.

Palavras Chave: Flotação de íons de ferro, remoção de ferro, flotação de precipitado, dodecil sulfato de sódio. 


\section{Introduction}

The presence of ferric ions may render the water inadequate for consumption in some industrial, commercial and residential applications. In concentrations above $0.3 \mathrm{ppm}$, iron imparts to water a yellowish coloration, bitter taste, and also stains materials.

Several techniques for the removal of metals are known. The most usual consists of iron precipitation in the hydroxide form, followed by sedimentation. However, the process is slow, becoming inadequate in situations of large liquid volumes or of high rates of pollutant dilution, due to the need of a large tank, besides requiring a subsequent filtration stage that delays the process.

The possibility of reducing the iron grade by flotation was studied.
This separation technique was suggested initially by Sebba (1962) and has been indicated for the recovery of metals (Zouboulis, 1995; Ghazy et al. 2006) as an analytical technique (Koh et al., 1990) and for the treatment of a wide variety of effluent, with organic (Morgan et al., 1992) or inorganic pollutants (Scorzelli et al., 1999; Huang et al., 2000).

Several advantages have been attributed to ion flotation: (1) efficiency in removal; (2) speed of the operation; (3) small space occupation; (4) production of small sludge volume; (5) possibility of selective removal; (6) application flexibility and (8) moderate costs (McIntyre et al., 1983).

Ion removal by flotation can take place: (1) through an electrical interaction between the polar part of the molecule of the collector and the contaminating species, forming a sublet that is transported to the surface by air bubbles introduced into the column; (2) through the formation of a precipitate, in the form of hydroxide or sulphate (Capponi et al., 2006) or (3) by absorbent particles used as a carrier agent (Sabti et al., 2002; Santander et al., 2011).

In an aqueous solution, ferric ion is strongly hydrated in the form of an aqueous complex, $\mathrm{Fe}\left(\mathrm{H}_{2} \mathrm{O}\right)_{6}{ }^{3+}$. It is considered that the positive charge of the metallic ion exercises a strong influence on the electrons of the molecules associated to the water, resulting in polarization and a tendency for proton dissociation (Gregory, 1978).

The following hydrolytic reactions are expected:

$$
\begin{gathered}
\mathrm{Fe}\left(\mathrm{H}_{2} \mathrm{O}\right)_{6}{ }^{3+}<==> \\
\left.\left.\left[\mathrm{Fe}(\mathrm{OH}) \cdot(\mathrm{OH}) \cdot\left(\mathrm{H}_{2} \mathrm{O}\right)_{5}\right]^{2+} \mathrm{O}\right)_{5}\right]^{2+}+\mathrm{H}^{+} \\
\mathrm{Fe}(\mathrm{OH})_{2} \cdot\left(\mathrm{H}_{2} \mathrm{O}\right)_{4}{ }_{4}^{+}<==>\left[\mathrm{Fe}(\mathrm{OH})_{2} \cdot\left(\mathrm{H}_{2} \mathrm{O}\right)_{4}\right]^{+}+\mathrm{H}^{+}
\end{gathered}
$$

The last product of the reaction is a precipitate of a colloidal hydroxide of iron, $\mathrm{Fe}(\mathrm{OH})_{3(S)}$. In the level of concentration used (50 ppm or about 8.9 $\mathrm{x} 10^{-4} \mathrm{moles} / \mathrm{L}$ ), the precipitation starts around pH 2.6 (Rubin and Johnson,

\section{Experiment}

\section{Reagents}

In flotation experiments the reagents used were: hexahydrated iron chloride as iron supplier, sodium dodecyl sulphate

\section{Water}

In all tests, ultra purified water through the Millipore "Academic" System was used. The system consists of pre-treat-

\section{Equipment}

The flotation tests were carried out in a glass column, $65 \mathrm{~cm}$ high and $5 \mathrm{~cm}$ in diameter, which had a porous plate and was fed by an airflow supplier, with rate controlled by a rotameter (Figure
1967) and it presents an isoelectric point close to $\mathrm{pH} 8$ (Weber Jr., 1975). In agreement with Rubin and Johnson (1967), the precipitate flotation of iron hydroxide can be efficient in systems with a concentration of metallic ions 100 times greater than that of the collector, contrarily to what happens in the flotation of soluble iron that requires at least a collector concentration similar to that of the metallic ions.
(SDS) as collector, and sodium hydroxide as $\mathrm{pH}$ regulating, all produced by Merck with a purity of $99 \%$. Nitric acid $(65 \%)$ and potassium thiocyanate (99\%), produced by Carlo Erba, were used for the determination of the iron content in water. ment through a filter and purification by reverse osmosis (River-5), followed by an ultra purification apparatus Milli-Q. The water produced presents a resistivity of 18mega ohm-cm, conductivity of $0 \mu \mathrm{S} . \mathrm{cm}^{-1}$ and total dissolved solids below $20 \mathrm{ppb}$.
1-A).The determination of the iron content was made by colorimetry, using a UV spectrophotometer, Spectronics model Genesis 2PC. The surface tension was determined by a Tensiometer KSV, model Sigma-70. The precipitates were analysed by a Transmission Electron Microscope (TEM) 100 CXII- Jeol. 


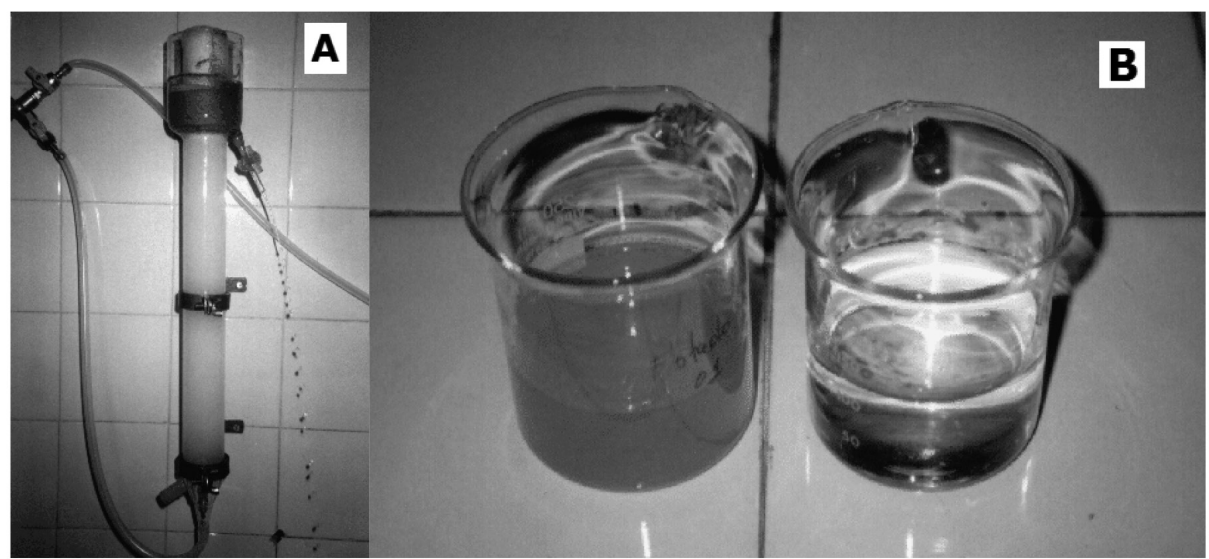

Method

The methodology used consisted of placing the solution of hexahydrate iron chloride in a $600 \mathrm{~mL}$ beaker, for conditioning with the SDS, for a pre-determined period, in a mechanical agitator with a constant speed of $1800 \mathrm{rpm}$.

\section{Results and discussion}

According to the results presented in Tables 1 and 2, the efficiency of the
In sequence, the sample was placed in the flotation column and a constant air flow rate of $0.2 \mathrm{~L} / \mathrm{min}$ was introduced. At the end of the test, the froth containing the iron ions was removed. The purification of the water was evaluated through the process is influenced by the concentration of the collector (SDS) and by the
Figure 1

(A) Column used in the flotation tests, the dark superior part shows the foam where the iron ions were concentrated and (B) the samples before (yellowish coloration) and after flotation (transparent water).

determination of the iron content in the water and by the determination of the surface tension in the residual product of each test. Transmission electron microscopy was used to observe the precipitate morphology and size.

conditioning time.

\begin{tabular}{c|c|c|c}
\hline \multirow{2}{*}{$\begin{array}{c}\text { CONCENTRATION } \\
\text { SDS, } \times 10^{-6} \mathrm{M}\end{array}$} & \multicolumn{3}{|c}{ CONDITIONING TIME, (minutes) } \\
\cline { 2 - 4 } & 5 & 10 & 20 \\
\hline 5 & 0 & 0 & 0 \\
\hline 10 & 0 & 0 & 61.2 \\
\hline 50 & 80.6 & 99.6 & 99.7 \\
\hline 80 & 99.8 & 99.9 & 99.8 \\
\hline 100 & 99.9 & 99.9 & 99.9 \\
\hline
\end{tabular}

\begin{tabular}{c|c|c|c}
\hline \multirow{2}{*}{$\begin{array}{c}\text { CONCENTRATION } \\
\text { SDS, } \times 10^{-6} \mathrm{M}\end{array}$} & 5 & 10 & 20 \\
\cline { 2 - 4 } & \multicolumn{3}{|c}{ CONDITIONING TIME, (minutes) } \\
\hline 5 & 50.0 & 50.0 & 50.0 \\
\hline 10 & 50.0 & 50.0 & 23.5 \\
\hline 50 & 11.0 & 0.21 & 0.18 \\
\hline 80 & 0.14 & 0.14 & 0.14 \\
\hline 100 & 0.09 & 0.08 & 0.03 \\
\hline
\end{tabular}

No removal of iron was observed with collector concentrations below 10 $5 \mathrm{M}$. With $10^{-5} \mathrm{M}$, the removal was partial $(61.2 \%)$ and only occurred in a test with a longer period of conditioning (20 minutes). Removal was practically total with $5 \times 10^{-5} \mathrm{M}$. For a concentration of SDS $10-4 \mathrm{M}$, removal of $99.9 \%$ of the iron contained in the original sample was achieved. That removal level allowed purified water with less than $0.1 \mathrm{ppm}$ of iron to be obtained. Figure 1-B displays the solution before and after removal of $\mathrm{Fe}^{3+}$ ions.

A series of tests with airflow rate of only $1 \mathrm{~L} / \mathrm{min}$ was done. The results, presented in Table 3, show that the process is improved by the increase in conditioning time. The residual iron content is reduced from $13.2 \%$ to $0.2 \%$,
Table 1

Variation of the amount of contaminants removed (\%) as a function of collector concentration and conditioning time. Tests carried out at $\mathrm{pH}=8$ with an airflow rate of $0.2 \mathrm{~L} / \mathrm{min}$.

\section{Table 2}

Variation of iron grade in purified water, as a function of collector concentration and conditioning time. Tests carried out at $\mathrm{pH}=8$ with an airflow rate of $0.2 \mathrm{~L} / \mathrm{min}$.

when conditioning time increases from 5 to 20 minutes. That fact suggests an increase in the precipitate size during the conditioning period. The precipitated growth was favored by the fact that the conditioning was carried out at $\mathrm{pH} 8$, close to the isoelectric point of the colloid (Weber Jr., 1975). Larger size precipitate floats more readily. The analysis of the precipitate by Transmission Electron Mi- 
croscope (TEM) confirms the hypothesis of growth. Comparing Figures 2 and 3,

Table 3

Influence of conditioning time on residual grade and percentage of iron removed. Tests carried out with SDS $\left(10^{-4} \mathrm{M}\right)$, at $\mathrm{pH}=8$, with an airflow rate of $1 \mathrm{~L} / \mathrm{min}$.

Figure 2

Photomicrograph $(x 1000)$ of the precipitate obtained in a solution of ferric chloride, at $\mathrm{pH} 8$ and 5 minutes of conditioning.

The increased size of precipitate implicates in a smaller value in the ratio collector ions precipitate necessary for efficient removal. As the concentration of SDS was maintained constant, the reduction

Figure 3

Photomicrography $(x 1000)$ of precipitate obtained in a solution of ferric chloride, at $\mathrm{pH} 8$, with 20 minutes of conditioning.

Figure 4

Surface tension of the purified water as a function of conditioning time. Flotation tests carried out with $10^{-4} \mathrm{M}$ of SDS, at it is observed that the colloidal particle resultants offing from the precipitation of iron form larger aggregates with 20 minutes of conditioning (Figure 3).

\begin{tabular}{c|c|c}
\hline $\begin{array}{c}\text { CONDITIONING } \\
\text { TIME (minutes) }\end{array}$ & $\begin{array}{c}\text { TREATED } \\
\text { WATER } \\
\text { Fe }(\%)\end{array}$ & $\begin{array}{c}\text { Fe IONS REMOVED } \\
(\%)\end{array}$ \\
\hline 5 & 13.2 & 82.9 \\
\hline 10 & 1.4 & 98.1 \\
\hline 15 & 0.7 & 99.1 \\
\hline 20 & 0.2 & 99.7 \\
\hline
\end{tabular}

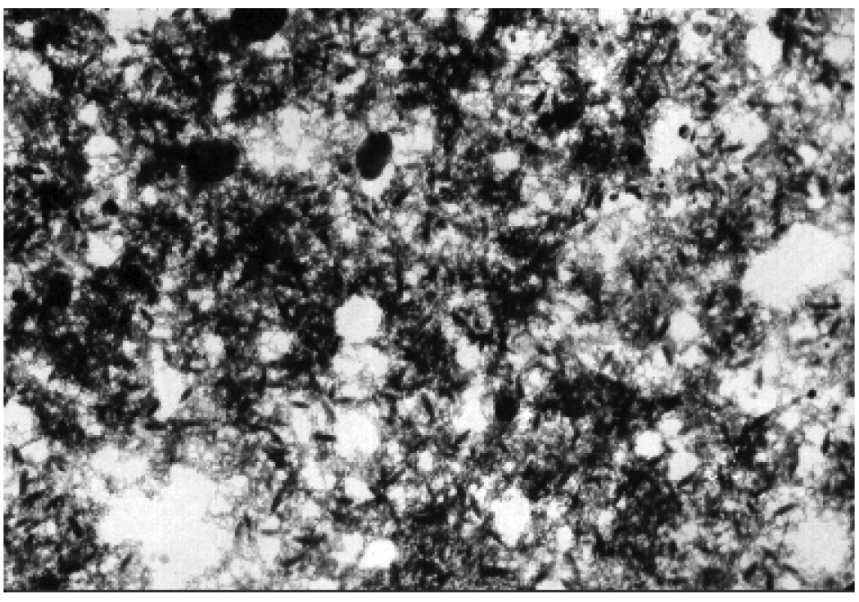

in the surface area of precipitate results in an increase of the residual concentration of the collector corresponding to the excess. That implicates in a reduction of the surface tension (Figure 4). The results presented in Figure 5 show that the surface tension of the treated water decreases from $63.3 \mathrm{mN} / \mathrm{m}$ to $60.9 \mathrm{mN} / \mathrm{m}$, when conditioning time increases from 5 to 20 minutes.
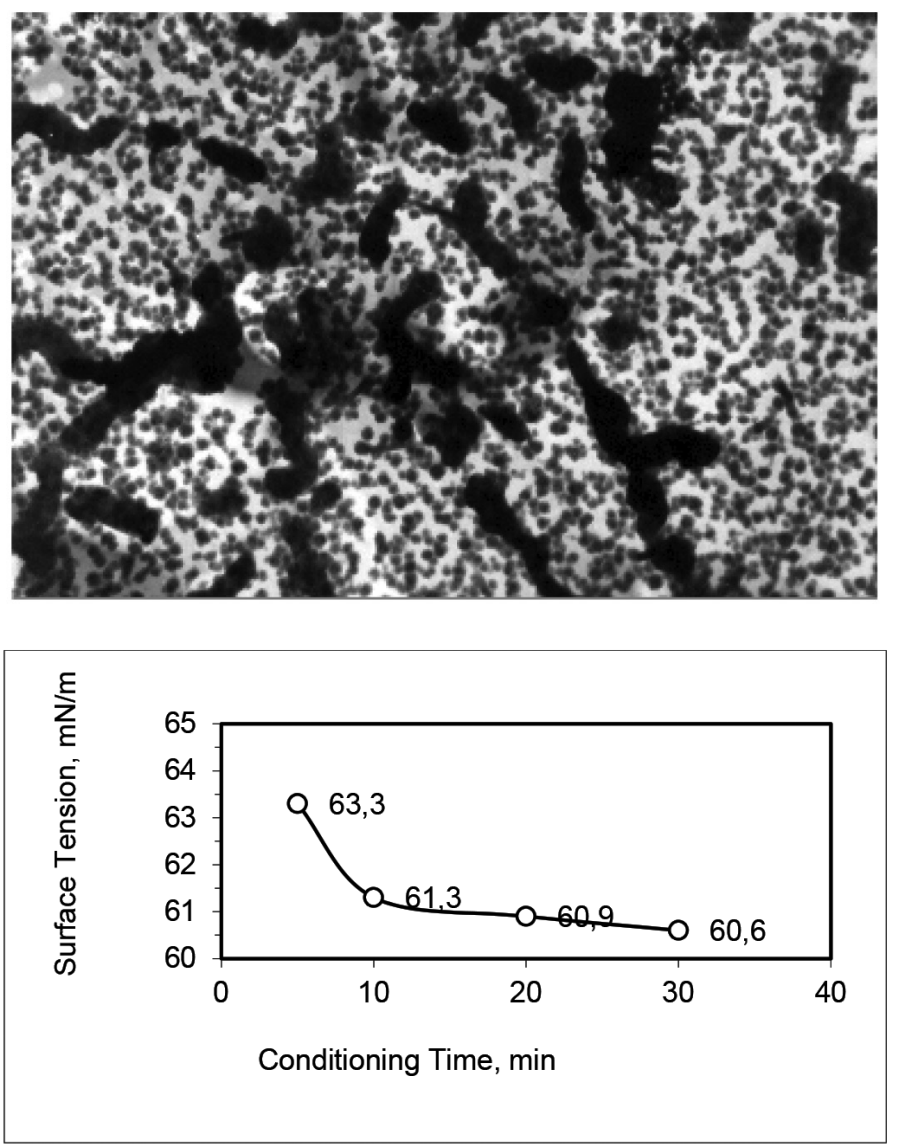


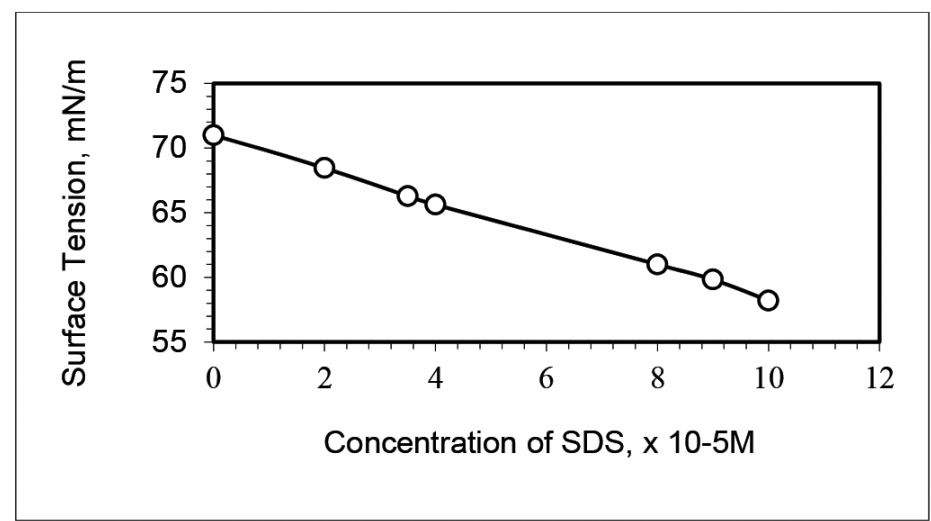

In agreement with data presented in Figure 5, surface tensions of $63.3 \mathrm{mN} / \mathrm{m}$ and $60.9 \mathrm{mN} / \mathrm{m}$ correspond to SDS concentrations of $6 \times 10^{-5} \mathrm{M}$ and

\section{Conclusions}

The removal of $\mathrm{Fe}^{3+}$ ions by flotation with sodium dodecyl sulphate (SDS) as collector was studied. The process was shown to be very efficient. Removal of $99.9 \%$ of the $\mathrm{Fe}^{3+}$ contained in the original solution was obtained. The water Fe3+content was
$8 \times 10^{-5} \mathrm{M}$, respectively. In other words, considering the initial collector concentration of $10^{-4} \mathrm{M}$, with the increase in conditioning time from 5 to 20 minutes,
Figure 5

Surface tension as a function of concentration of SDS.

the concentration of SDS, required for $\mathrm{Fe}^{3+}$ ion flotation, is decreased from $4 \times 10^{-5} \mathrm{M}$ to $2 \times 10^{-5} \mathrm{M}$.

\section{References}

reduced from $50 \mathrm{ppm}$ to less than 0.1 ppm.

The collector conditioning time, a parameter usually not considered strongly relevant, exerted an important influence on the flotation process. The increase in conditioning time of the SDS solution implies in a growth of the precipitate that caused a reduction of $50 \%$ of in the collector consumption due to the reduction in the total aggregate surface area. This effect is favored at $\mathrm{pH} 8$ near to the isoelectric point.

GHAZY, S.E.,MAHMOUD, I.A.,RAGAB, A.H. Removal of copper (II) from aqueous solutions by flotation using polyaluminum chloride silicate (PAX-X160 S) as coagulant and carbonate ions as activator. Environmental Technology, v.27, n.1, p.53-61, 2006.

GREGORY, J. Flocculation by inorganic salts.In: K.J. Ives (Editor), The Scientific Basis of Flocculation. Sijthoff\&Noordhoff, 1978. p.89. IVES, K.J (Ed.).

HUANG, S.D.,SU, P.G.,HUANG, S.P.,HO, Y.L.,TSAI, T.Y. Adsorbing colloid flotation with polyaluminum chloride: a powerful technique for removing heavy metals from wastewater. Separation Science and Technology, v.35, n.98, p. 1223-1232, 2000.

$\mathrm{KOH}, \mathrm{T}$., NAGANUMA, Y., SAGAWA, M.A preconcentration method for spectrophotometric determination of thiocyanate by means of macromolecular ion flotation. Analytical Science, v.6, n.6, p. 893, 1990.

McINTYRE, G., RODRIGUEZ, J.J., THACKSTON, E.L., WILSON, D.J. Inexpensive heavy metal removal by foam flotation. Journal WPCF, v.55, p.9, 1983.

MORGAN, J.D., NAPPER, D.H., WARR, G.G. Kinetics of recovery of hexadecyltrimethylammonium bromide by flotation. Langmuir, v.8, n.9, p. 2124, 1992.

RUBIN, A.J., JOHNSON, J.D. Effect of $\mathrm{pH}$ on ion and precipitate flotation systems. Analytical Chemistry, v.39, n.3, p. 298, 1967.

SABTI, H., BROOKS, R.R., STEWART, R.B., HOSSAIN, M. Adsorbing colloid flotation for removal of metal ions in waters from base metal mines. Environmental Progress, v.21, n.1, p. 63-69, 2002.

SANTANDER, M., VALDERRAMA, L., GUEVARA, M., RUBIO, J.Adsorbing colloidal flotation removing metals ions in a modified jet cell. Minerals Engineering, v.24, n.9, p.1010-1015, 2011.

SCORZELLI, I.B., FRAGOMENI, A.L., TOREM, M.L. Removal of cadmium from a liquid effluent by ion flotation. Minerals Engineering, v.12, n.8, p.905, 1999.

SEBBA, F. Ion flotation. Elsevier Publishing Company, 1962.

WEBER, Jr., W.J. Physicochemical processes for water quality control. John Wiley \& Sons. 1975. p.75.

ZOUBOULIS, A.I. Silver recovery from aqueous streams using ion flotation. Minerals Engineering, v.8 n.12, p. 1477, 1995. 